\title{
TEST TAKERS' ATTITUDES TO THE TEST CONTENT OF THE TWO LISTENING TESTS: IELTS AND TOEFL IBT
}

\author{
Nguyen Thi Nhan Hoa* \\ VNU International School, 99 Nguy Nhu Kon Tum, Thanh Xuan, Hanoi, Vietnam
}

Received 01 July 2018

Revised 27 July 2018; Accepted 30 July 2018

\begin{abstract}
Ten aspects of test content in the two listening tests: IELTS and TOEFL iBT are investigated from the perspective of test-takers' judgment. Main findings reveal that there are both similarities and differences in test takers' attitudes to the two tests although the similarities outweigh the differences. The most obvious difference is that test takers have a more positive attitude to the IELTS listening test than to the TOEFL iBT listening test and test preparation has a strong effect to test takers' attitude to the test. In addition, test takers' positive attitudes to the test are strongly associated with better test performance. Substantial differences of test takers' attitude to the two listening tests can be seen in their judgment of difficulty level, new words/technical terms and familiarity of topics. Test takers found the IELTS listening test less difficult, having fewer new words and technical terms, and containing more familiar topics than the TOEFL iBT listening test. They also find the test method of the IELTS is less challenging than that of the TOEFL iBT listening test although their choice of the test to take heavily depends on which test they are being prepared for.
\end{abstract}

Keywords: IELTS listening test, TOEFL iBT listening test, test-takers' attitudes, test content, test method, test difficulty level, test performance, test choice

This study investigates test-takers' attitudes to the test content across the IELTS and the TOEFL iBT listening tests - the two international English tests which are worldwide used to measure English language proficiency for non-native language learners. In the Vietnamese context, it has also been widely used to measure English language proficiency of EFL students although there are various opinions among English language learners relating to the choice of either IELTS or TOEFL iBT.

\section{Reasons to investigate the test content}

Although test-takers' perception of test content can be considered a component of

\footnotetext{
* Tel.: 84-1236439978

Email: nguyenthinhanhoa@gmail.com
}

construct validity, there are debates about the status of test takers' feedback. The researcher of this study takes the view that test takers' perceptions are indeed relevant to test validity. There are several reasons behind this conception.

Firstly, test takers should be engaged in the test so that they can perform to the best of their ability. This can only be done if the test content is familiar to them and they believe that the test can reflect their true ability. Test takers' engagement in the test can contribute to the test construct validity as Bachman and Palmer (1996) discussed. It can be assumed that test takers are inexpert judges and thus their opinions should not be considered. In addition, whether or not they like the test, they have to take it anyway. For example, a patient does not 
like an injection, but $\mathrm{s} / \mathrm{he}$ still has to take it in order to overcome the illness. However, if $\mathrm{s} / \mathrm{he}$ knows about the process s/he will go through with the injection, the patient will cope with it better and might feel less pain. Similarly, a test taker might not like the test but $\mathrm{s} /$ he has to take it in order to be accepted into a university. Still, if s/he feels positive with the test, s/he can lower his anxiety and thus can give the best performance to his/her ability.

Secondly, test takers' opinions are important because additional features of the task as well as additional challenges emerging while processing the task, which are not visible by test designers or test raters, might be discovered by test takers (Elder, Iwashita, \& McNamara, 2002). Test takers and test stake holders often have strong belief in test content. In order to enhance the construct validity of a test, it is necessary to combine the understanding of test designers, test stake holders and test takers. However, the voice of test takers has been least heard so far (Hamp-Lyons, 2000).

\section{Research contexts and participants}

Participants in the study were 107 Vietnamese students who were taking IELTS or TOEFL preparation courses in Hanoi to study overseas in English-speaking countries. The IELTS preparation group consisted of 54 candidates and the TOEFL preparation group was comprised of 53 candidates. Both groups were provided and had a trial with the test they were not prepared for before taking the tests. 95 candidates taking the two tests under test-taking conditions (providing quantitative data) and 12 candidates took the two tests with think-aloud protocols (providing qualitative data). Think-aloud in the context of this study means a pause was given after each block of listening questions to allow test-takers to verbalise what they were thinking while forming their answers to each item in the test.

\section{Instruments}

\subsection{Listening tests}

The test materials used in the study were the IELTS Specimen listening test versions 2005 and the TOEFL iBT practice test online 2005. While this may place certain constraints on the validity of the study, it should be noted that the IELTS Specimen practice test published by the British Council, IDP IELTS Australia, and University of Cambridge ESOL Examinations is closer to the actual IELTS test than any other commercially available IELTS practice test. Similarly, the TOEFL iBT practice test available online 2005 closely simulates the real TOEFL iBT test. The summary description of items and listening passages in the IELTS and TOEFL iBT used in the study is as follows:

Table 1. Description of IELTS Specimen listening test 2005

\begin{tabular}{|l|l|}
\hline $\begin{array}{l}\text { Section 1: [conversation]: An interview between a policeman } \\
\text { and a witness }\end{array}$ & $\begin{array}{l}10 \text { questions/ testing items } \\
\text { Questions 1 to } 10\end{array}$ \\
\hline $\begin{array}{l}\text { Section 2: [monologue]: A recorded message giving } \\
\text { information about an English hotel. }\end{array}$ & $\begin{array}{l}10 \text { questions/ testing items } \\
\text { Questions 11 to 20 }\end{array}$ \\
\hline $\begin{array}{l}\text { Section 3: [conversation]: Three students talking about their } \\
\text { study programs. }\end{array}$ & $\begin{array}{l}10 \text { questions/ testing items } \\
\text { Questions 21 to 30 }\end{array}$ \\
\hline $\begin{array}{l}\text { Section 4: [monologue]: A talk by a university lecturer in } \\
\text { Australia on a type of bird in Tasmania. }\end{array}$ & $\begin{array}{l}10 \text { question / testing items } \\
\text { Question 31 to 40 }\end{array}$ \\
\hline
\end{tabular}


Table 2. Description of TOEFL iBT listening practice test 2005

\begin{tabular}{|l|l|}
\hline \multicolumn{2}{|c|}{ Part 1: 17 questions/ testing items } \\
\hline $\begin{array}{l}\text { Conversation 1.1: A talk between a lecturer and a student } \\
\text { about her missing from class and the handout she missed. }\end{array}$ & $\begin{array}{l}5 \text { questions/ testing items } \\
\text { Questions 1 to 5 }\end{array}$ \\
\hline Lecture 1.1: Biology: sound development in birds & $\begin{array}{l}6 \text { questions/ testing items } \\
\text { Questions 6 to 11 }\end{array}$ \\
\hline Lecture 1.2: History: the development of a historical place. & $\begin{array}{l}6 \text { questions/ testing items } \\
\text { Questions 12 to 17 }\end{array}$ \\
\hline \multicolumn{2}{|c|}{ Part 2: 17 questions/ testing items } \\
\hline $\begin{array}{l}\text { Conversation 2.1: A talk between a student and a librarian } \\
\text { about looking for reference books in the library }\end{array}$ & $\begin{array}{l}5 \text { questions/ testing items } \\
\text { Questions 18 to 22 }\end{array}$ \\
\hline $\begin{array}{l}\text { Lecture 2.1: Business } \\
6 \text { questions/ testing items } \\
\text { Questions 23 to 28 }\end{array}$ \\
\hline Lecture 2.2: Astronomy & $\begin{array}{l}6 \text { questions/ testing items } \\
\text { Questions 29 to } 34\end{array}$ \\
\hline
\end{tabular}

\subsection{Aspects of test content to be investigated} and the questionnaire of test content

A comparison of test takers' attitude to the IELTS and the TOEFL iBT listening tests will be examined by (i) exploring test takers' general attitude to the test, (ii) performing correlations between test takers' attitudes to the test and test scores across both the IELTS and the TOEFL iBT listening tests, and (iii) investigating test takers' attitude to each dimension of test content, namely:

Aspect 1: the test as a whole (Part A of the questionnaire)

Aspect 2: the test instructions (Part B of the questionnaire)

Aspect 3: prediction before listening (Part $\mathrm{C}$ of the questionnaire)

a. the reading questions and the effect of reading questions before listening (the IELTS listening test), and

b. the visual stimulus and its effect on comprehension and concentration (the TOEFL iBT listening test)
Aspect 4: the challenge of reading questions, listening to stimulus and writing answers at the same time (the IELTS listening test) versus answering questions after listening to the stimulus (the TOEFL iBT listening test,) (Part D of the questionnaire)

Aspect 5: the time allocation (i) to check and transfer the answers (in the IELTS listening test), (ii) to read questions, answer and check the answer (in the TOEFL iBT listening test) (Part $\mathrm{E}$ of the questionnaire)

Aspect 6: the difficulty level of each section in the test (Part F of the questionnaire)

Aspect 7: the new words, technical terms in each section of the test (Part G of the questionnaire)

Aspect 8: the topic familiarity of each section of the test (Part $\mathrm{H}$ of the questionnaire)

Aspect 9: the relation between the test and listening ability (Part I of the questionnaire)

Aspect 10: the challenging level of the two tests and test takers' preference for one or the other (Part K of the questionnaire) 
See the full questionnaire in Appendix 1A and Appendix 1B for the detailed aspects of test takers' reflection on the two tests investigated in this study.

\section{Data analysis and findings}

4.1. Test takers' general attitude to the IELTS and the TOEFL iBT listening tests
The 31 item questionnaire (given to the test takers after they had finished each listening test) investigates test takers' attitude to the IELTS and the TOEFL iBT listening tests. These items cover 10 components of test content and comparison as listed above. For each item, test-takers were asked to judge their degree of agreement or disagreement by ticking an appropriate box as indicated below:

\begin{tabular}{|c|c|c|c|c|c|}
\hline (6) & (5) & (4) & (3) & (2) & (1) \\
\hline $\begin{array}{c}\text { strongly } \\
\text { agree }\end{array}$ & agree & slightly agree & $\begin{array}{c}\text { slightly } \\
\text { disagree }\end{array}$ & disagree & $\begin{array}{c}\text { strongly } \\
\text { disagree }\end{array}$ \\
\hline
\end{tabular}

In order to quantify responses and allow a comparison of test takers' attitudes across the two listening tests, responses to negatively worded items were recoded so that all 'agree' and 'strongly agree' responses on the Likertscale were indicators of 'positive' attitude (feeling good about the test and its components).

The software program of Quest analyses was used to measure the degree to which testtakers' had a positive attitude to the test. The positive logit values are indicative of positive attitudes reflecting the fact that 'strongly agree' items were recoded as 6, 'strongly disagree' as $1^{1}$.

The numbers of test takers with the positive values (for the IELTS and TOEFL iBT listening test respectively) shown in table 3 below reveal that those with a generally positive attitude to the IELTS listening test are greater in number than is the case with the TOEFL iBT listening test (54 vs. 41).

Table 3. A comparison of test takers' positive attitude to the test across the IELTS and the TOEFL iBT listening tests

\begin{tabular}{|c|c|c|c|c|}
\hline \multirow{2}{*}{} & \multicolumn{2}{|c|}{$\begin{array}{c}\text { Positive attitude to the IELTS listening } \\
\text { test }(\mathrm{n}=95)\end{array}$} & $\begin{array}{c}\text { Positive attitude to the TOEFL iBT } \\
\text { listening test }(\mathrm{n}=95)\end{array}$ \\
\cline { 2 - 5 } & $\begin{array}{c}\text { The IELTS } \\
\text { preparation group } \\
(\mathrm{n}=48)\end{array}$ & $\begin{array}{c}\text { The TOEFL } \\
\text { preparation } \\
\text { group } \\
(\mathrm{n}=47)\end{array}$ & $\begin{array}{c}\text { The IELTS } \\
\text { preparation } \\
\text { group } \\
(\mathrm{n}=48)\end{array}$ & $\begin{array}{c}\text { The TOEFL } \\
\text { preparation group } \\
(\mathrm{n}=47)\end{array}$ \\
\hline $\begin{array}{c}\text { In each test } \\
\text { preparation group }\end{array}$ & $\begin{array}{c}17 \\
(42.55 \%)\end{array}$ & $\begin{array}{c}13 \\
(27.65 \%)\end{array}$ & $\begin{array}{c}28 \\
(59.57 \%)\end{array}$ \\
\hline $\begin{array}{c}\text { Total positive } \\
\text { responses }\end{array}$ & \multicolumn{2}{|c|}{$\begin{array}{c}54 / 95 \\
(56.84 \%)\end{array}$} & \multicolumn{2}{|c|}{$\begin{array}{c}41 / 95 \\
(43.16 \%)\end{array}$} \\
\hline
\end{tabular}

This finding that test takers had a more positive attitude to the IELTS listening test than to the TOEFL iBT listening test was confirmed by the mean attitude logit values: (.14 and 0 for the IELTS and the TOEFL iBT listening tests respectively.) This means that the test-takers tended to have slightly positive attitude to the IELTS listening test and a

1 Tables listing logit values of each test taker's attitude to the two tests study can be provided by emailing the author. 
neutral attitude to the TOEFL iBT listening test. From here two issues will be investigated further: (i) Is the difference between test takers' attitudes to the two listening tests statistically significant? (ii) Is there any significant correlation across test takers' attitudes across these two listening tests? With regard to the first issue, a Paired Sample T-test shows that the difference was not significant $(t=1.987$, $\mathrm{p}>.05)$. As for the second issue, the result of a Pearson correlation 2-tailed $(\mathrm{r}=.239, \mathrm{p}=$ .019 or $\mathrm{p}<.05$ ) was significant indicating that attitudes to one test were strongly associated with attitudes to the other.

In addition, there is tentative evidence of the effect of test preparation on test takers' attitude to the test as shown in table 3. The numbers of test takers with positive attitudes to each test were unequally distributed across the two test preparation groups: more test takers from the IELTS preparation group felt positive about the IELTS listening than test takers from the TOEFL iBT preparation group (37 vs. 17 respectively). Similarly, more test takers from the TOEFL preparation felt positive about the TOEFL iBT listening test than test takers from the IELTS preparation group (28 vs. 13 respectively).

Test takers' attitude to each component of the IELTS and the TOEFL iBT listening tests will be analysed and discussed in detail in section 4.3.
4.2. Correlation between test takers' positive attitude to the test and test scores across the IELTS and the TOEFL iBT listening tests

As argued in reason to investigate the test content above one of the reasons for investigating the test takers' reactions to the test is that a positive attitude to the test might lower test takers' anxiety and thus enhance their performance. The correlation between test takers' attitude towards each test and their performance will determine if that is the case.

Across both tests, the statistical values support the argument that test takers' positive attitudes to the test are associated with better test performance $(\mathrm{r}=.412, \mathrm{p}=.000$; and $\mathrm{r}=$ $.595, \mathrm{p}=.000)$. This correlation is significant across both the IELTS and the TOEFL iBT listening tests $(p<.001)$. However, the relationship is stronger in the TOEFL iBT listening test than in the IELTS listening test $(\mathrm{r}=.595$ vs. $\mathrm{r}=.412$ respectively).

\subsection{Test takers' attitude to each component of test content}

\subsubsection{Aspect 1: Test takers' attitude to the test as a whole}

There were 5 items asking test-takers to indicate their attitudes to the test as a whole (Part A of the questionnaire): (1) the level of interest, (2) the test length, (3) the speech rate, (4) the accents and (5) the overall difficulty level. Test-takers judgments are summed up in the following table.

Table 4. Test takers' average mean judgments of the test as a whole

\begin{tabular}{|c|c|c|c|c|c|c|c|c|c|c|c|}
\hline \multicolumn{2}{|c|}{$\begin{array}{l}\text { A. ABout THE } \\
\text { TEST AS A WHOLE }\end{array}$} & \multicolumn{2}{|c|}{ A1 } & \multicolumn{2}{|c|}{$\underline{\mathrm{A} 2}$} & \multicolumn{2}{|c|}{$\underline{\mathrm{A} 3}$} & \multicolumn{2}{|c|}{$\underline{\mathrm{A} 4}$} & \multicolumn{2}{|c|}{$\underline{\mathrm{A} 5}$} \\
\hline $\mathrm{N}$ & $\begin{array}{l}\text { Valid: } 95 \\
\text { Missing: } 0\end{array}$ & IELTS & $\begin{array}{l}\text { TOEFL } \\
\text { iBT }\end{array}$ & IELTS & $\begin{array}{l}\text { TOEFL } \\
\text { iBT }\end{array}$ & IELTS & $\begin{array}{l}\text { T O E F L } \\
\text { iBT }\end{array}$ & IELTS & $\begin{array}{l}\text { TOE F L } \\
\text { iBT }\end{array}$ & IELTS & $\begin{array}{l}\text { TOEFL } \\
\text { iBT }\end{array}$ \\
\hline$\underline{\mathrm{Me}}$ & & $\underline{4.60}$ & 4.79 & $\underline{2.76}$ & 2.41 & $\underline{3.64}$ & $\underline{3.45}$ & $\underline{3.25}$ & 3.37 & $\underline{3.95}$ & $\underline{4.43}$ \\
\hline $\mathrm{Me}$ & & 5 & 5 & 2 & 2 & 4 & 4 & 3 & 3 & 4 & 4 \\
\hline Std. & eviation & 1.07 & 1.02 & 1.18 & 1.18 & 1.22 & 1.07 & 1.13 & 1.17 & 1.26 & .95 \\
\hline
\end{tabular}


Note:

$6=$ strongly agree, $5=$ agree, $4=$ slightly agree, 3 = slightly disagree, $2=$ disagree, $1=$ strongly disagree

A1. I found the test interesting.

A2. I found the test short.

A3. I found the speech rate fast.

A4. I found some of the accents difficult to understand.

\section{A5. I found the test difficult overall}

Generally, there are no differences across the IELTS and the TOEFL iBT listening tests in test takers' judgments of (1) interest level (2) length, (3) speech rate, and (4) accents.

The only noticeable difference in test takers' attitude to the test in general was their judgment of the overall difficulty level of each test. They tended to agree that the TOEFL iBT listening test was difficult overall but only slightly agreed that the IELTS listening test was difficult overall (means of $4.43 \mathrm{vs} .3 .95$ respectively). This difference in difficulty level across the two tests was large and statistically significant (Wilcoxon 2-tailed $\mathrm{z}=-3.369, \mathrm{p}=$ $.001)$. See section 4.3.6 in this paper for more detailed results and a discussion of test takers' judgments of difficulty level across the two listening tests in general and each section of the test in particular.

\subsubsection{Aspect 2: Test takers' judgment to the test instructions}

Test takers tended to find test instructions on both the IELTS and the TOEFL iBT listening tests clear. The median and the mode value of 5 indicating agreement confirm this tendency.

\subsubsection{Aspect 3: Reading questions or seeing} visual stimulus before listening to the text

In the IELTS listening test, already noted, test takers are given time to read questions in each section before they listen to the listening stimulus. In the TOEFL iBT listening test, they can see the topic of the listening text and a visual stimulus before the listening stimulus begins. Part $C$ in the questionnaire investigates test takers attitude to reading questions or a seeing visual stimulus before listening to the listening text.

Table 5. Test takers' judgments of reading questions (IELTS) and seeing visual stimulus (TOEFL iBT)

\begin{tabular}{|c|c|c|c|c|c|c|c|}
\hline \multicolumn{4}{|c|}{$\begin{array}{l}\text { C. READING QUESTIONS AND THE EFFECT OF READING } \\
\text { QUESTIONS BEFORE LISTENING (IELTS) }\end{array}$} & \multicolumn{4}{|c|}{$\begin{array}{l}\text { C. VISUAL STIMULUS AND ITS EFFECT ON COMPREHENSION } \\
\text { AND CONCENTRATION (TOEFL IBT) }\end{array}$} \\
\hline N Valid: & & & & Valid: & & & \\
\hline \multicolumn{4}{|l|}{ Missing: 0} & \multicolumn{4}{|l|}{ Missing: 0} \\
\hline & IELTS C1 & IELTS C2 & IELTS C3 & & $\begin{array}{l}\text { TOEFL } \\
\text { iBT Cl }\end{array}$ & $\begin{array}{l}T O E F L \\
i B T C 2\end{array}$ & $\begin{array}{l}\text { TOEFL } i B T \\
\quad C 3\end{array}$ \\
\hline Mean & $\underline{4.64}$ & $\underline{5.29}$ & $\underline{3.51}$ & Mean & $\underline{4.25}$ & $\underline{2.87}$ & $\underline{4.73}$ \\
\hline Median & 5 & 5 & 4 & Medium & 4 & 3 & 5 \\
\hline Std. Deviation & 1.09 & .77 & 1.27 & Std. Deviation & 1.19 & 1.23 & 1.11 \\
\hline
\end{tabular}


Note:

$6=$ strongly agree, $5=$ agree, $4=$ slightly agree, 3 = slightly disagree, $2=$ disagree, $1=$ strongly disagree

IELTS C1. I was given enough time to read questions before listening.

IELTS C2. I found reading the questions before listening helped my comprehension.

IELTS C3. I found it difficult to remember the questions I read before listening.

TOEFL iBT C1. I found the visual stimulus (e.g classroom, lecturer's office or a library scene) helped my comprehension.

TOEFL iBT C2. I found visual stimulus (e.g classroom, lecturer's office or a library scene) distracting as it stayed on the screen.

TEOFL iBT C3. I found that technical terms and/or an illustrative picture (of what the lecturer was saying) on the screen helped my comprehension.

The mean (and also median) for item IELTS $\mathrm{C} 1$ both show that test takers found the time given to read questions before they listened to the stimulus in the IELTS listening test sufficient. Consequently, they found it not very difficult to remember the questions they read before listening (item IELTS C3).

With regard to the effect of reading questions (item IELTS C2) or seeing the visual stimulus (item TOEFL iBT C1) before listening to the stimulus, test takers found these preview opportunities helpful to their comprehension. However, they found reading questions before listening to stimulus in the IELTS listening test more helpful than the visual stimulus in the TOEFL iBT listening test (mean $=5.29$ vs. 4.25 ). This difference is very large and significant (Wilcoxon 2-tailed z
$=-6.219, \mathrm{p}=.000)$. In addition, there was little variation in their attitude to the effective impact of previewing questions before listening in the IELTS listening (standard deviation of only .770). An in-depth analysis reveals that up to 87 test takers (or 91.6\% of them) "agreed" or "strongly agreed" that reading questions before listening to the stimulus helped them comprehend the listening text better. In other words, test takers seem to have a strong belief in the usefulness of seeing questions before actually listening to the text. (Information on test takers' reaction to reading questions after having listened to the listening stimulus in the TOEFL iBT is provided in the next part when questionnaire items D are compared.)

In contrast to the positive attitude to the usefulness of viewing questions before listening, test takers were not so optimistic about the effect of context visual stimulus on their comprehension. The average mean of their attitude to this item was 4.25 , indicating slight agreement. In fact, only 45 (or $47.4 \%$ of test takers) "agreed" or "strongly agreed" that seeing the visual stimulus before listening helped their comprehension.

In addition to context visual stimulus, in the TOEFL iBT listening test, content visual stimulus such as technical terms and/or an illustrative picture (of what the lecturer was saying) also appear on the screen while test takers are listening to the text. Test takers found the content visual stimulus very useful to their comprehension (item TOEFL iBT C3) as the mean average, the mode and the median are around 5 indicating an agreement. This findings is coherent with what Ginther (2001) found in her research on the effect of visuals on performance of TOEFL CBT Listening-Comprehension: "when the visual presented information that complemented the audio text... their presence facilitated performance" (p. 25). 
4.3.4. Aspect 4: Answering questions in the listening tests

In the IELTS listening test, test takers listen to the stimulus and write their answers at the same time. In the TOEFL iBT listening test, they listen to the whole stimulus of a conversation or lecture and then answer the questions. Section D in the questionnaire investigates their attitude to this structure of the listening tests and the findings are summarized in the following table.

Table 6. Test takers' attitude to questions across the two tests (the IELTS and the TOEFL iBT listening tests)

\begin{tabular}{|c|c|c|c|c|c|}
\hline $\begin{array}{l}\text { D. CHALLENGE OF READING QUESTIONS, } \\
\text { LISTENING TO STIMULUS AND WRITING } \\
\text { ANSWERS (IELTS) }\end{array}$ & D1 & D2 & $\begin{array}{l}\text { D. BEING GIVEN QUESTIONS AFTER } \\
\text { LISTENING TO THE STIMULUS AND } \\
\text { ANSWERING (TOEFL) }\end{array}$ & D1 & D2 \\
\hline $\begin{array}{l}\mathrm{N} \quad \text { Valid: } 95 \\
\text { Missing: } 0\end{array}$ & IELTS & IELTS & $\begin{array}{l}\text { Valid: } 95 \\
\text { Missing: } 0\end{array}$ & $\begin{array}{l}T O E F L \\
i B T\end{array}$ & TOEFL $i B T$ \\
\hline Mean & $\underline{4.09}$ & $\underline{4.06}$ & Mean & $\underline{4.01}$ & $\underline{4.72}$ \\
\hline Median & 4 & 4 & Median & 4 & 5 \\
\hline Std. Deviation & 1.20 & 1.11 & Std. Deviation & 1.42 & 1.00 \\
\hline
\end{tabular}

Note:

$6=$ strongly agree, $5=$ agree, $4=$ slightly agree, $3=$ slightly disagree, $2=$ disagree, $1=$ strongly disagree

IELTS D1. I found it difficult to manage listening to the stimulus, looking at the question, and writing the answers at the same time

IELTS D2. As I had to listen to the stimulus for several questions, I found it challenging to match a question with the listening stimulus I was listening to.

TOEFL iBT D1. I found seeing the questions after I had listened to the whole listening stimulus (of each conversation or lecture) helped my comprehension.

TOEFL iBT D2. Controlling the speed of answering the questions within 20 minutes given in this test was good for my performance.

At first sight, the mean of 4.09 for item D1 suggests that test takers did not find listening to the stimulus, looking at the question, and writing the answers at the same time in the IELTS listening test very difficult. Similarly, they did not think matching a question with the listening stimulus they were listening to in this test (item D2) was very challenging (mean $=4.06)$. However, the relatively large standard deviation $(>1)$ suggests that there was considerable variability in response to this item. A closer analysis revealed that around $40 \%$ of test takers "agreed" or "strongly agreed" that these activities were challenging to them. The difficulty is likely due to the complexity of activities of: (1) listening to the stimulus, reading the questions and writing the answers at the same time, and (2) matching the question with the stimulus while listening. The interviews with think-aloud participants below revealed the reasons for the challenge of this test method to the IELTS listening test takers. 


\begin{tabular}{|c|c|}
\hline Original in Vietnamese & English translation \\
\hline $\begin{array}{l}\text { D. Trong bài thi, bạn phải vì̀a nghe bài } \\
\text { nghe, vì̀a nhìn vào câu hỏi, đồng thời viết } \\
\text { câu trả lời } \\
\text { Câu 1. Hoạt động này có gì khó đối với bạn? }\end{array}$ & $\begin{array}{l}\text { D. In the test, you had to listen to the stimulus, } \\
\text { look at the questions and write down the answers } \\
\text { at the same time. } \\
\text { Question 1: How did you find this activity? }\end{array}$ \\
\hline tT130 & tT130 \\
\hline $\begin{array}{l}\text { Đấy là khó khăn chung của những người thi } \\
\text { IELTS đều bị tình trạng như vậy cả. }\end{array}$ & $\begin{array}{l}\text { This is the common challenge to all IELTS tes } \\
\text { takers }\end{array}$ \\
\hline $\begin{array}{l}\text { tT96 } \\
\text { Khó. Nhiều chỗ phải viết tắt... nhiều chỗ } \\
\text { nghe được rồi nhưng mình viết đầy đủ là đứt } \\
\text { luôn... ví dụ như chỗ } 17 \text { dễ nghe, lúc nghe } \\
\text { nghe được nhưng do viết thông tin là bị miss } \\
\text { luôn. }\end{array}$ & $\begin{array}{l}\text { tT96 } \\
\text { Difficult. Many places }[\mathrm{I}] \text { had to take short-hand... } \\
\text { Many questions }[\mathrm{I}] \text { could catch the information but } \\
\text { I wrote in full forms so got lost... For example, } \\
\text { it was easy to catch information for question 17. I } \\
\text { could catch it but I was busy to write down other } \\
\text { information so I missed it. }\end{array}$ \\
\hline $\begin{array}{l}\text { iT28 } \\
\text { Em thấy nó cũng như thói quen của mình } \\
\text { ở trên lớp thôi vì mình vẫn vừa nghe vừa } \\
\text { viết... tuy nhiên có nhiều lúc mình nghe được } \\
\text { từ đấy nhưng mình nghe rất là... là... quen } \\
\text { nhưng mình lại không nhớ là phải viết như } \\
\text { thế nào và nghĩ thế là mình bị bỏ lỡ những từ } \\
\text { khác... bị lỡ những thông tin khác tiếp theo. }\end{array}$ & $\begin{array}{l}\text { iT28 } \\
\text { I think it was just like my habit in the class as I } \\
\text { often have to listen and write down at the same } \\
\text { time... However, there were times I could hear } \\
\text { the words and these words sound very... very } \\
\text { familiar but I didn't remember their spellings and } \\
\text { I thought about them thus I missed other words... } \\
\text { missed other incoming information }\end{array}$ \\
\hline $\begin{array}{l}\text { iT18 } \\
\text { Đôi khi rất là khó nếu mà từ đọc quá nhanh } \\
\text { mà em không có kỹ năng viết tắt lắm. }\end{array}$ & $\begin{array}{l}\text { iT18 } \\
\text { Sometimes it was difficult if the speech rate was } \\
\text { too fast and also I did not have skills of taking } \\
\text { short-hand. }\end{array}$ \\
\hline
\end{tabular}

In contrast to the IELTS, in the TOEFL iBT listening test, test takers can control the speed of answering questions within the total of 20 minutes given. Item TOEFL iBT D2 shows that test takers thought that control over the speed was good for their performance (mean $=4.72$ ). In fact, 67 (or $70.52 \%$ of test takers) "agreed" or "strongly agreed" about its benefits.

Item TOEFL iBT D1 investigates the effect of seeing and reading questions after having listened to the listening stimulus of the whole conversation or lecture to test takers' comprehension. Test takers seem to be divided in their attitude to this issue (standard deviation $=1.42$ ). Although the mean (4.01) suggests that they generally "slightly disagreed" with the statement that "seeing the questions after I had listened to the whole listening stimulus (of each conversation or lecture) helped my comprehension", there were 44 (or $46.31 \%$ of test takers) who "agreed" or "strongly agreed" with that statement. In other words, test takers had different attitudes to this method of the TOEFL iBT listening test: while many thought it was helpful, many others did not think so.

Compared to the test method of the IELTS listening test: reading questions before listening to the stimulus (item IELTS C2), test takers seem to find it much more helpful than the test method of the TOEFL iBT listening test: reading questions after having listened to the whole listening stimulus (item TOEFL iBT D1): mean $=5.29$ vs. 4.01 respectively. This difference is very large and significant (Wilcoxon 2-tailed $\mathrm{z}=-5.976, \mathrm{p}=.000$ ). 


\subsubsection{Aspect 5: Time allocation to answering questions}

In the IELTS listening test, test takers answer the questions while listening, thus they are given time to check their answer and by the end of the test, to transfer them onto the answer sheet. In the TOEFL iBT test takers only see the questions after the whole listening stimulus of a conversation or lecture finishes, thus they have to use given time to read questions, answer them and check each of them before moving to the next item. Part $\mathrm{D}$ in the questionnaire investigates test takers' attitude to this feature of the two tests.

Table 7. Test takers' attitude to time allocation to answering questions across the two tests (the IELTS and the TOEFL iBT listening tests)

\begin{tabular}{|l|l|l|l|l|l|}
\hline $\begin{array}{l}\text { E.TIME ALLOCATION TO CHECK AND } \\
\text { TRANSFER THE ANSWERS (IELTS) }\end{array}$ & E1 & E2 & E3 & $\begin{array}{l}\text { E. TIME ALLOCATION TO READ QUESTIONS, } \\
\text { ANSWER ANDCHECK THE ANSWERS(TOEFL) }\end{array}$ & E1 \\
\hline $\begin{array}{l}\text { Valid: } 95 \\
\text { Missing: } 0\end{array}$ & IELTS & IELTS & IELTS & $\begin{array}{l}\text { N Valid: } 95 \\
\text { Missing: } 0\end{array}$ & $i B T$ \\
\hline Mean & $\underline{4.40}$ & $\underline{3.76}$ & $\underline{4.94}$ & Mean & 4.78 \\
\hline Median & 5 & 4 & 5 & Median & 5 \\
\hline Std. Deviation & 1.29 & 1.57 & 1.19 & Std. Deviation & 1.12 \\
\hline
\end{tabular}

Note:

$6=$ strongly agree, $5=$ agree, $4=$ slightly agree, 3 = slightly disagree, $2=$ disagree, $1=$ strongly disagree

IELTS E1: I had enough time to check my answers after listening to each section stimulus.

IELTS E2: I found the one minute allowed for checking all my answers at the end of the test sufficient.

IELTS E3: I found the 10 minutes allowed for transferring my answers to the answer sheet sufficient.

TOEFL iBT E1: I found the overall time of 20 minutes given to answer all the questions in this listening test sufficient.
The means of all items show that across both tests, test takers generally found they had sufficient time to check the answer (in the IELTS listening test) and to answer and check the answers (in the TOEFL iBT listening test).

\subsubsection{Aspect 6: Difficulty of each section in} the test

In part $\mathrm{F}$ of the questionnaire, test takers were asked to indicate their perception regarding the difficulty level of each section (the conversation, monologue, or lecture) in each test by stating their level of agreement with the statement: "I found this section difficult." The following table summarizes test takers' judgments of each section and the mean of all sections in each test.

Table 8. Difficulty level of each section across the two listening tests (the IELTS and the TOEFL iBT)

\begin{tabular}{|c|c|c|c|c|c|c|c|c|c|c|}
\hline \multirow[b]{2}{*}{$\begin{array}{l}\text { F. DIFFICULTY } \\
\text { LEVEL OF EACH } \\
\text { SECTION IN THE } \\
\text { TEST } \\
\mathrm{N} \\
\text { Valid: } 95 \\
\text { Missing: } 0\end{array}$} & \multicolumn{4}{|c|}{ The IELTS Listening test } & \multicolumn{6}{|c|}{ The TOEFL iBT Listening test } \\
\hline & $\begin{array}{c}\text { F1 Section } \\
1 \text { (everday } \\
\text { conver- } \\
\text { sation) }\end{array}$ & $\begin{array}{c}\text { F2 Section } \\
2 \text { (everday } \\
\text { mono- } \\
\text { logue) }\end{array}$ & $\begin{array}{c}\text { F3 Section } \\
3 \text { (academic } \\
\text { conver- } \\
\text { sation) }\end{array}$ & $\begin{array}{c}\mathrm{F} 4 \\
\text { Section } 4 \\
\text { (academic) } \\
\text { mono- } \\
\text { logue) }\end{array}$ & $\begin{array}{c}\text { F1 } \\
\text { Part 1 } \\
\text { Conver- } \\
\text { sation 1 }\end{array}$ & $\begin{array}{c}\text { F2 } \\
\text { Part } 1 \\
\text { Lecture } \\
1 \text { (mono- } \\
\text { logue } \\
\text { lecture) }\end{array}$ & $\begin{array}{c}\text { F3 } \\
\text { Part 1 } \\
\text { Lecture 2 } \\
\text { (interac- } \\
\text { tive } \\
\text { lecture) }\end{array}$ & $\begin{array}{c}\text { F4 } \\
\text { Part } 2 \\
\text { Conversation } \\
2\end{array}$ & $\begin{array}{c}\text { F5 } \\
\text { Part } 2 \\
\text { Lecture } \\
3 \text { (mono- } \\
\text { logue } \\
\text { lecture) }\end{array}$ & $\begin{array}{c}\text { F6 } \\
\text { Part } 2 \\
\text { Lecture } 4 \\
\text { (interac- } \\
\text { tive } \\
\text { lecture) }\end{array}$ \\
\hline$\underline{\text { Mean }}$ & $\underline{3.03}$ & $\underline{3.48}$ & $\underline{4.17}$ & $\underline{4.59}$ & $\underline{3.08}$ & $\underline{3.94}$ & $\underline{4.78}$ & $\underline{3.16}$ & $\underline{4.78}$ & $\underline{5.40}$ \\
\hline \multirow[t]{2}{*}{ Average mean } & \multicolumn{2}{|c|}{$\underline{3.25}$} & \multicolumn{2}{|c|}{4.38} & \multirow{2}{*}{\multicolumn{6}{|c|}{4.19}} \\
\hline & \multicolumn{4}{|c|}{$\underline{3.82}$} & & & & & & \\
\hline Median & 3 & 4 & 4 & 5 & 3 & 4 & 5 & 3 & 5 & 6 \\
\hline Std. Deviation & 1.27 & 1.19 & 1.12 & 1.05 & .93 & .88 & .86 & .86 & .67 & .86 \\
\hline
\end{tabular}


Note:

$6=$ strongly agree, $5=$ agree, $4=$ slightly agree, 3 = slightly disagree, $2=$ disagree, $1=$ strongly disagree

IELTS F1, 2, 3, 4, and TOEFL iBT F1, 2, 3, 4, 5, 6: "I found this section difficult."

Several points emerge from table 8 . Firstly, the average mean of all sections across the two tests shows that test takers found the TOEFL iBT listening test more difficult than the IELTS listening test (4.19 vs. 3.82). This is rather consistent across all sections of the two tests and it again confirms that test takers in general found the TOEFL iBT listening test more challenging than the IELTS listening test.

\subsubsection{Aspect 7: New words/technical terms in each section of the test}

Assuming that new words or technical terms might affect test takers' listening comprehension, section $\mathrm{G}$ in the questionnaire asks test takers to judge whether there were too many of them in each listening section they had just done. Their answers are summed up in table 9 below.

Table 9. New words/ technical terms in each section across the two listening tests (the IELTS and the TOEFL iBT)

\begin{tabular}{|c|c|c|c|c|c|c|c|c|c|c|}
\hline \multirow[t]{2}{*}{$\begin{array}{l}\text { G. NEW } \\
\text { WORDS/ } \\
\text { TECHNICAL } \\
\text { TERMS } \\
\text { OF EACH } \\
\text { SECTION IN } \\
\text { THE TEST } \\
\text { N Valid: } 95 \\
\quad \text { Missing: } 0\end{array}$} & \multicolumn{4}{|c|}{$\begin{array}{l}\text { The IELTS Specimen listening test } 2005 \\
\text { Section 1: An interview between police and the } \\
\text { witness. } \\
\text { Section 2: A recorded message giving information } \\
\text { about an English hotel. } \\
\text { Section 3: Three students talking about their study } \\
\text { programs. } \\
\text { Section 4: A talk by a university lecture in Australia } \\
\text { on a type of bird in Tasmania. }\end{array}$} & \multicolumn{6}{|c|}{$\begin{array}{l}\text { The TOEFL iBT practice listening test } 2005 \\
\text { Conversation 1: A talk between a lecturer and a student about her missing form } \\
\text { class and the hand out she missed. } \\
\text { Lecture 1: Biology: The sound development in birds } \\
\text { Lecture 2: History: The development of a historical place. } \\
\text { Conversation 2: A talk between a student and a librarian about looking for } \\
\text { reference books in the library } \\
\text { Lecture 3: Business } \\
\text { Lecture 4: Astronomy }\end{array}$} \\
\hline & $\begin{array}{c}\text { G1 } \\
\text { Section } 1 \\
\text { (every-day } \\
\text { conver- } \\
\text { sation) }\end{array}$ & $\begin{array}{l}\text { G2 Section } \\
2 \text { (every- } \\
\text { day mono- } \\
\text { logue) }\end{array}$ & $\begin{array}{l}\text { G3 Section } \\
3 \text { (aca- } \\
\text { demic } \\
\text { conver- } \\
\text { sation) }\end{array}$ & $\begin{array}{c}\text { G4 Section } \\
4 \text { (aca- } \\
\text { demic } \\
\text { mono- } \\
\text { logue) }\end{array}$ & $\begin{array}{c}\text { G1 } \\
\text { Part } 1 \\
\text { Conver- } \\
\text { sation 1 }\end{array}$ & \begin{tabular}{|c|} 
G2 \\
Part 1 \\
Lecture \\
1 (mono- \\
logue \\
lecture) \\
\end{tabular} & $\begin{array}{c}\text { G3 } \\
\text { Part 1 } \\
\text { Lecture 2 } \\
\text { (interac- } \\
\text { tive } \\
\text { lecture) } \\
\end{array}$ & $\begin{array}{c}\text { G4 } \\
\text { Part } 2 \\
\text { Conversation } \\
2\end{array}$ & \begin{tabular}{|c|} 
G5 \\
Part 2 \\
Lecture \\
3 (mono- \\
logue \\
lecture) \\
\end{tabular} & $\begin{array}{c}\text { G6 } \\
\text { Part } 2 \\
\text { Lecture } 4 \\
\text { (interac- } \\
\text { tive } \\
\text { lecture) }\end{array}$ \\
\hline Mean & $\underline{2.61}$ & $\underline{2.78}$ & $\underline{3.47}$ & $\underline{4.41}$ & $\underline{2.80}$ & $\underline{4.32}$ & $\underline{5.09}$ & 2.93 & $\underline{4.11}$ & $\underline{5.56}$ \\
\hline$\underline{\text { Mean average }}$ & \multicolumn{2}{|c|}{$\underline{2.69}$} & \multicolumn{2}{|c|}{$\underline{3.94}$} & \multicolumn{6}{|c|}{$\underline{4.14}$} \\
\hline Median & 2 & 3 & 3 & 5 & 3 & 4 & 5 & 3 & 4 & 6 \\
\hline Std. Deviation & 1.08 & 1.07 & 1.14 & 1.09 & .67 & .62 & .70 & .68 & .53 & .72 \\
\hline
\end{tabular}

Note:

$6=$ strongly agree, $5=$ agree, $4=$ slightly agree, 3 = slightly disagree, $2=$ disagree, $1=$ strongly disagree

IELTS G1, 2, 3, 4, and TOEFL iBT G1, 2, 3, 4, 5, 6: "I found that this section has many new words/technical terms."

The TOEFL iBT listening test was perceived to have more new words/technical terms than the IELTS listening test overall (4.14 vs. 3.32). It is also worth mentioning that specific topics such as the development of a historical place (in America) and Astronomy (Pluto) in the TOEFL iBT test were perceived by test takers as having many new words/ technical terms than others. Nearly all test takers $(100 \%$ and $98.94 \%$ of them) agreed that they found that these two lectures had many new words/ technical terms. 
4.3.8. Aspect 8: Familiarity of topic of each section in the test to test takers

As discussed in the literature review, topic familiarity also has a certain influence on listeners' comprehension. Section H of the questionnaire asks tests takers to judge whether each topic across the two listening tests was familiar to them. Table 10 below summarizes their judgments.

Table 10. Familiarity of topic in each section across the two listening tests

(the IELTS and the TOEFL iBT)

\begin{tabular}{|c|c|c|c|c|c|c|c|c|c|c|}
\hline $\begin{array}{lr}\text { H. } & \text { TOPIC } \\
\text { FAMILIARITY } \\
\text { OF } \quad \text { EACH } \\
\text { SECTIONINTHE } \\
\text { TEST } \\
\mathrm{N} \\
\text { Valid: } 95\end{array}$ & \multicolumn{4}{|c|}{$\begin{array}{l}\text { The IELTS Specimen listening test } 2005 \\
\text { Section 1: An interview between police } \\
\text { and the witness. } \\
\text { Section 2: A recorded message giving } \\
\text { information about an English hotel. } \\
\text { Section 3: Three students talking about } \\
\text { their study programs. } \\
\text { Section 4: A talk by a university lecture } \\
\text { in Australia on a type of bird in Tasmania. }\end{array}$} & \multicolumn{6}{|c|}{$\begin{array}{l}\text { The TOEFL iBT practice listening test } 2005 \\
\text { Conversation 1: A talk between a lecturer and a student about her } \\
\text { missing form class and the hand out she missed. } \\
\text { Lecture 1: Biology: The sound development in birds } \\
\text { Lecture 2: History: The development of a historical place. } \\
\text { Conversation 2: A talk between a student and a librarian about } \\
\text { looking for reference books in the library } \\
\text { Lecture 3: Business } \\
\text { Lecture 4: Astronomy }\end{array}$} \\
\hline Missing: 0 & $\begin{array}{c}\text { H1 } \\
\text { Section } \\
1 \\
\text { (every- } \\
\text { day } \\
\text { conver- } \\
\text { sation) }\end{array}$ & $\begin{array}{c}\mathrm{H} 2 \\
\text { Section } \\
2 \\
\text { (every- } \\
\text { day } \\
\text { mono- } \\
\text { logue) }\end{array}$ & $\begin{array}{c}\text { H3 } \\
\text { Section } \\
3 \text { (aca- } \\
\text { demic } \\
\text { conver- } \\
\text { sation) }\end{array}$ & $\begin{array}{c}\mathrm{H} 4 \\
\text { Section } \\
4 \text { (aca- } \\
\text { demic) } \\
\text { lecture) }\end{array}$ & $\begin{array}{c}\text { H1 } \\
\text { Part } 1 \\
\text { Conver- } \\
\text { sation } 1\end{array}$ & $\begin{array}{c}\mathrm{H} 2 \\
\text { Part } 1 \\
\text { Lecture } \\
1 \\
\text { (mono- } \\
\text { logue } \\
\text { lecture) }\end{array}$ & $\begin{array}{c}\mathrm{H} 3 \\
\text { Part } 1 \\
\text { Lecture } \\
2 \\
\text { (interac- } \\
\text { tive } \\
\text { lecture) }\end{array}$ & $\begin{array}{c}\mathrm{H} 4 \\
\text { Part } 2 \\
\text { Conver- } \\
\text { sation } 2\end{array}$ & $\begin{array}{c}\text { H5 } \\
\text { Part } 2 \\
\text { Lecture } \\
3 \\
\text { (mono- } \\
\text { logue } \\
\text { lecture) }\end{array}$ & $\begin{array}{c}\text { G6 } \\
\text { Part } 2 \\
\text { Lecture } \\
4 \\
\text { (interac- } \\
\text { tive } \\
\text { lecture) }\end{array}$ \\
\hline$\underline{\text { Mean }}$ & $\underline{4.48}$ & $\underline{4.48}$ & $\underline{4.43}$ & $\underline{3.26}$ & $\underline{4.99}$ & $\underline{3.65}$ & $\underline{3.42}$ & $\underline{4.84}$ & $\underline{3.59}$ & $\underline{1.93}$ \\
\hline \multirow[t]{2}{*}{ Mean average } & \multicolumn{2}{|c|}{$\underline{4.48}$} & \multicolumn{2}{|c|}{$\underline{3.84}$} & \multirow{2}{*}{\multicolumn{6}{|c|}{$\underline{3.74}$}} \\
\hline & \multicolumn{4}{|c|}{$\underline{4.16}$} & & & & & & \\
\hline Median & 5 & 5 & 5 & 3 & 5 & 4 & 3 & 5 & 4 & 2 \\
\hline Std. Deviation & 1.00 & .861 & .919 & 1.20 & .51 & .56 & .69 & .42 & .62 & .99 \\
\hline
\end{tabular}

Note:

$6=$ strongly agree, $5=$ agree, $4=$ slightly agree, 3 = slightly disagree, $2=$ disagree, $1=$ strongly disagree

IELTS H1, 2, 3, 4, and TOEFL iBT H1, 2, $3,4,5,6$ : "I felt that the topic of this section was familiar."

Overall test takers felt that the topics of listening sections in the IELTS listening test were more familiar to them than those in the TOEFL iBT listening test (4.16 vs. 3.74). Topic unfamiliarity level can contribute to the difficulty level of a test as found by other researchers such as Chiang and Dunkel (1992), Long (1990), Markham and Latham (1987), and Schmidt-Rinehart (1994) and (Celestine \& Ming, 1999), this can partly explain why test takers found the TOEFL iBT listening test more difficult than the IELTS listening test.

\subsubsection{The relation between the test and test takers' listening ability}

The most interesting aspect of test takers' attitude to the test is probably their belief in the fairness of the test itself. Section $\mathrm{I}$ in the questionnaire investigates if test takers thought the score on each test would reflect their true listening ability. 
Table 11. Test takers' judgments of relation between the test and their listening ability across the two listening tests (the IELTS and TOEFL iBT)

\begin{tabular}{|l|c|c|}
\hline \multicolumn{1}{|c|}{$\begin{array}{c}\text { I. RELATION BETWEEN THE TEST AND LISTENING ABILITY } \\
\text { Valid: } 95\end{array}$} & $\begin{array}{c}\text { The IELTS Specimen } \\
\text { listening test 2005 }\end{array}$ & $\begin{array}{c}\text { TOEFL iBT practice } \\
\text { listening test 2005 }\end{array}$ \\
\hline $\mathrm{N}$ & $\underline{4.22}$ & $\underline{4.44}$ \\
\hline Mean & 4 & 4 \\
\hline Median & 5 & 5 \\
\hline Mode & .97 & .89 \\
\hline Std. Deviation & & \\
\hline
\end{tabular}

Note:

$6=$ strongly agree, $5=$ agree, $4=$ slightly agree, 3 = slightly disagree, $2=$ disagree, $1=$ strongly disagree

IELTS I1 and TOEFL iBT I1: "The score on this test will reflect my true listening ability"

Generally, test takers' responses indicated an agreement that their scores on both the IELTS and the TOEFL iBT listening tests were a true reflection of their listening ability. The raw data reveals that $76(80 \%$ of test takers) and 80 (84.21\% of them) believed so. Though test takers' belief in the fairness of the TOEFL iBT listening test was stronger than that for the IELTS test (4.44 vs. 4.22), the difference was very small (.22) and not statistically significant (Wilcoxon 2-tailed $\mathrm{z}=$ $-1.517, p=.129)$. In other words, we can say that test takers shared a similar belief in the capacity of the two listening tests to measure their listening ability.

\subsubsection{Aspect 10: Comparing the two test and making a choice}

The last item in the questionnaire, item $\mathrm{K}$, asks test takers to make a comparison between the two listening tests in terms of level of challenge and their preference for one or the other of them. Test takers' perception of the two listening tests is summed up in the following table:

Table 12. Test takers' general comparison of the two listening tests

(the IELTS and the TOEFL iBT)

\begin{tabular}{|l|c|c|}
\hline $\begin{array}{l}\text { K. COMPARING TWO TEST AND MAKING A CHOICE } \\
\mathrm{N} \quad \begin{array}{l}\text { Valid: } 95 \\
\text { Missing: } 0\end{array}\end{array}$ & $\mathrm{~K} 1$ & $\mathrm{~K} 2$ \\
\hline Mean & $\underline{3.85}$ & $\underline{3.71}$ \\
\hline Median & 4 & 4 \\
\hline Mode & 5 & $4(5,6)$ \\
\hline Std. Deviation & 1.54 & 1.70 \\
\hline
\end{tabular}

Note:

$6=$ strongly agree, $5=$ agree, $4=$ slightly agree, 3 = slightly disagree, $2=$ disagree, $1=$ strongly disagree

K1: "In general I found the TOEFL listening test more challenging than the IELTS listening test."

K2: "If I had a choice, I would prefer to sit for the IELTS listening test rather than the TOEFL listening test." 
The mean shows that test takers' response fell between "slightly agree" and "slightly disagree" categories, which indicates that the TOEFL iBT listening test was perceived to be more challenging than the IELTS listening test (3.85). The raw data reveals that more than half of test takers agreed that the TOEFL iBT listening test was more challenging than the IELTS listening test as shown in the figure 1 below.

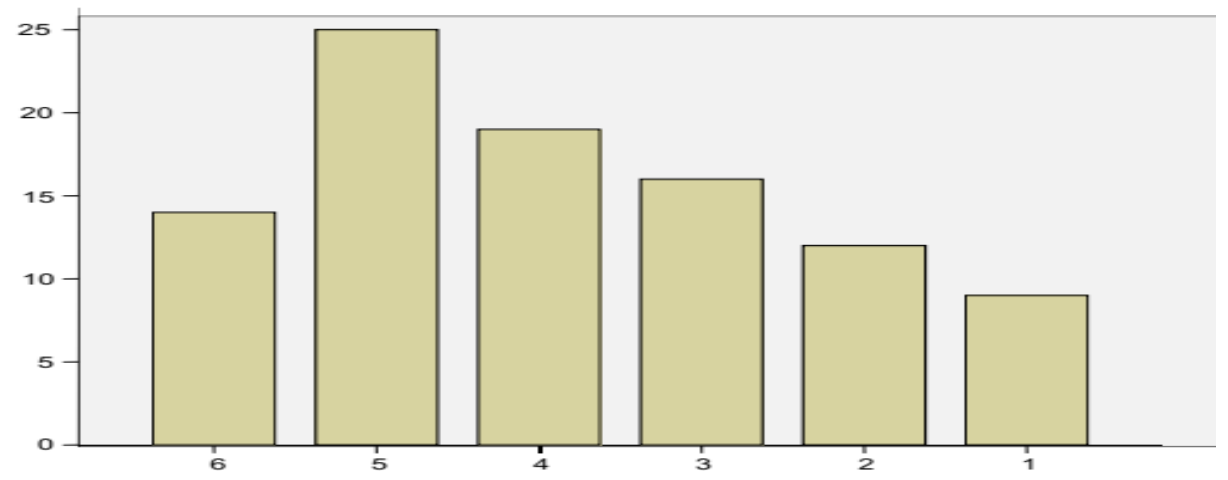

Note: 6: strongly agree, 5: slightly agree, 4: agree, 3: disagree, 2: slightly disagree, 1 : strongly disagree

Figure 1. Test takers' judgments "the TOEFL listening test was more challenging than the IELTS listening test"

However the standard deviation of 1.54 indicates that test takers' opinions on the relative challenge levels of the two tests varied widely. This large variation is also evident for item K2 (preference for the IELTS vs. the
TOEFL iBT listening tests). The mean of 3.71 indicates that their responses were between "slightly agree" and "slightly disagree" indicating that they would choose the IELTS listening. A closer analysis of the raw data, however, shows that they were almost evenly split in half for their preference either for the IELTS or the TOEFL iBT listening test as indicated in figure 2 below.

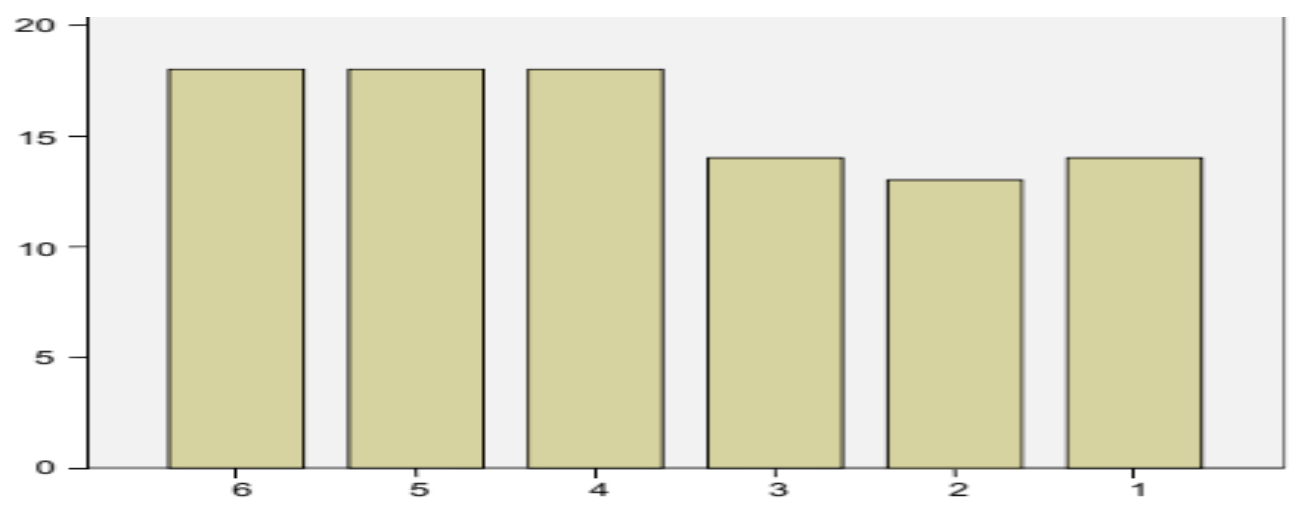

Note: 6: strongly agree, 5: slightly agree, 4: agree, 3: disagree, 2: slightly disagree, 2: strongly disagree

Figure 2. Test takers' preference of the IELTS listening test to the TOEFL listening test 
In short, no clear pattern can be seen in section $\mathrm{K}$ of the questionnaire. Test takers were split nearly 50-50 in their judgments as to whether the TOEFL iBT listening test was more challenging than the IELTS listening test. Similarly, they were split nearly evenly in their preference for one or the other test.
The interview data from the think-aloud participants reveal that the core of the preference for one or the other test related to which test the test takers had prepared for rather than to the nature of the test itself as shown below.

\begin{tabular}{l}
\hline Original questions and answers in Vietnamese \\
\hline $\begin{array}{l}\text { Câu K2: Nếu được phép lưa chọn, bạn sẽ chọn } \\
\text { bài thi nào, bài thi nghe TOEFL hay bài thi } \\
\text { nghe IELTS? }\end{array}$ \\
\hline $\begin{array}{l}\text { Participant tT121: Thi bài nào cũng được, phụ } \\
\text { thuộc vào mình đi học nước nào. Người ta yêu } \\
\text { cầu bài nào thì mình thi bài đấy. } \\
\text { Nhưng em đã ôn TOEFL nhiều rồi nên sẽ thi } \\
\text { TOEFL }\end{array}$ \\
\hline $\begin{array}{l}\text { Participant iT18: Có lẽ vẫn phải chọn IELTS } \\
\text { vì IELTS em luyện nhiều hơn và em tin là em } \\
\text { làm tốt hơn. } \\
\text { Còn nếu em được luyện thi đầy đủ cả } 2 \text { bài thì } \\
\text { không quan trọng bài nào cũng được... vì xét } \\
\text { cho cùng thì mỗi cái có cái hay của nó nhưng } \\
\text { phải để thời gian luyện thêm... }\end{array}$ \\
\hline
\end{tabular}

As (i) test preparation appears to be the main factor determining test preference and (ii) the number of participants in this study is nearly equal across the IELTS and the TOEFL preparation groups, the evenly split preference for each test cannot be considered a meaningful finding and may simply be a function of the sample in the current study.

\section{Summary and discussion of test content from test takers' perspective}

There are both similarities and differences in test takers' perceptions across the two listening tests: the IELTS and TOEFL iBT.

- Similarities are found in their perception about (i) the two tests in general,
Item K2: If you could make a choice, which test would you sit for: the IELTS listening test or the TOEFL iBT listening test?

Participant tT121: Any test will be OK, depending on which country I am going to study in. I'll sit for the test they require me to take.

However, I have already prepared a lot for the TOEFL so I will sit for the TOEFL test

Participant iT18: Perhaps [I] have to choose the IELTS test because I have prepared more for it and thus I believe I will do it better.

If I am prepared well for both tests, it is not important which test I will sit for... as in fact, each test is interesting in its own way but more preparation time is needed...

(ii) test instructions, (iii) time allocation, (iv) relation between the test and their selfassessed listening ability. In general, test takers found both tests interesting, not unduly short, not too fast in speech rate, not difficult to understand in terms of accents used in the listening stimulus, and not too difficult overall. They also found the test instructions clear and the time allocation for reading questions, recording answers and checking the answers sufficient. More importantly, they agreed that score obtained from each of these two tests could reflect their true listening ability. The finding that IELTS listening test is fair is coherent with what Cotton and Conrow (1998) found in their study in which students ranked the listening sub-test as the fairest one in the IELTS battery. 
- Substantial differences across the two listening tests can be seen in difficulty level, new words/technical terms and familiarity of topics. Test takers found the IELTS listening test less difficult, having fewer new words and technical terms, and containing more familiar topics than the TOEFL iBT listening test.

- The most noticeably significant difference is test takers' attitude to the different test methods between the two tests. They found reading questions before listening to stimulus in the IELTS listening test more helpful than just seeing the visual stimulus but NOT viewing questions in the TOEFL iBT listening test. This belief in the effect of reading questions before listening of test takers is consistent with what Buck's (1991) reported in his study: all test takers agreed that they would have understood less without questions preview. Similarly, Sherman (1997) remarked that "previewed questions [in a listening test] seem more helpful than they really are" (p. 185).

- The visual stimulus in the TOEFL iBT listening test did not distract test takers as one might surmise though it stays on the screen. This finding is contradictory with that of Ginther (2002) who found that the "context-only visual" in the mini-talk of the old TOEFL listening test had a slightly negative effect on performance. It is, however, consistent with what Ockey (2007) found in his study comparing the engagement of test takers in two types of visual in the listening tests: the still image and the video; test takers in Ockey's study engaged "minimally" and "similarly" with the still images.

- Test takers' positive attitudes to the test might be strongly influenced by their test performance. For example, test takers' raw scores on the IELTS listening test were slightly higher than their scores on the TOEFL iBT listening test (19.65 vs. 18.40 respectively), and this might be a factor in their more positive attitude to the IELTS than to the TOEFL iBT listening test (.14 vs. .00 respectively). This finding was similar to what Bradsaw (1990) and Brown (1993), Elder, Iwashita, \& McNamara (2002), Shohamy (1982), Zeidner (1988), Zeidner (1990) noticed about the relationship between scores obtained and test takers' attitudes to test task: weaker candidates respond less positively than higher level candidates. In other words, lower scores were likely to be associated with less positive attitudes to the test.

- Test takers' have no clear preference for either of the test. Approximately half of them would choose the IELTS listening test and the other half would choose the TOEFL iBT listening test. Their choice of test as well as their positive feeling to each test heavily depends on which test they are being prepared for.

All these analyses reveal that except for the test method and difficulty level, the test content and construct of the IELTS and the TOEFL iBT listening tests are perceived to be similar rather than different from test takers' perspective. This finding might be true to the comparison of the IELTS and TOEFL listening and with the sample of participants in this study. In a larger context, researchers must be cautious when using test takers' reflection on the test as evidence of validity as they often based on their particular experience and in a particular context. Nevertheless, this finding is beneficial for test preparation instructors as well as test takers, particularly in Vietnamese context because test method and test difficulty level are factors significantly contributing to test performance.

\section{References}

Bradsaw, J. (1990). Test takers' reactions to a placement test. Language Testing, 7, 13-30.

Brown, A. (1993). The role of test taker feedback in the test development process: test takers' reactions to a taped-mediated test of proficiency in spoken 
Japanese. Language Testing, 10, 277-303.

Buck, G. (1991). The testing of listening comprehension: an introspective study. Language testing, 8(1), 67-91.

Celestine, C., \& Ming, C. S. (1999). The Effect of Background Disciplines on IELTS Scores. In R. Tulloh (Ed.), IELTS Research Reports (Vol. 2, pp. 36-51). Canberra: IELTS Australia Pty Limited.

Cotton, F., \& Conrow, F. (1998). An investigation of the predictive validity of IELTS amongst a sample of international students at the University of Tasmania. In S. Wood (Ed.), IELTS Research Report (Vol. 1).

Elder, C., Iwashita, N., \& McNamara, T. (2002). Evaluating the difficulty of oral proficiency tasks: what does test takers have to offer? Language Testing, 19(4), 347-368.

Foster, P., Tonkyn, A., \& Wigglesworth, G. (2000). Measuring spoken language: a unit for all reasons. Applied Linguistics, 21(3), 354-375.

Ginther, A. (2001). Effects of the Presence and Absence of Visuals on Performance on TOEFL CBT Listening-Comprehension Stimuli (No. RR-01-16).
Ginther, A. (2002). Context and content visuals and performance on listening comprehension stimuli. Language Testing, 19, 133-167.

Hamp-Lyons, L. (2000). Social, professional and individual responsibility in language testing. System, 28, 579-591.

Ockey, G. J. (2007). Construct implications of including still image or video in computer-based listening tests. Language Testing, 24(4), 517-537.

Sherman, J. (1997). The effect of question preview in listening comprehension tests. Language testing, 14(2), 185-213.

Shohamy, E. (1982). Affective consideration in language testing. The Modern Language Journal, 66, 13-17.

Zeidner, M. (1988). Sociocultural differences in exmainees' attitudes toward scholastic ability exams. Journal of Educational Measurement, 25(1), 67-76.

Zeidner, M. (1990). Colleage students' reactions towards key facets of classroom testing. Assessment and evaluation in higher education, 15, 151-169.

\title{
THÁI ĐỘ CỦA THÍ SINH VỚI HAI BÀI THI NGHE TIẾNG ANH: IELTS VÀ TOEFL iBT
}

\author{
Nguyễn Thị Nhân Hòa \\ Khoa Quốc tế, ĐHQGHN, 99 Ngụy Nhur Kon Tum, Thanh Xuân, Hà Nội, Việt Nam
}

Tóm tắt: 10 phương diện trong nội dung của hai bài thi nghe: IELTS và TOEFL iBT được nghiên cứu từ góc độ đánh giá của thí sinh làm bài thi. Nghiên cứu cho thấy các thí sinh cảm nhận điểm giống nhau giữa hai bài thi này vượt trội hơn so với điểm khác biệt. Điểm khác biệt rõ nhất là thái độ lạc quan hơn của thí sinh với bài thi IELTS so với bài thi TOEFL iBT; thái độ của thí sinh với bài thi cũng chịu tác động mạnh của yếu tố học và luyện thi. Ngoài ra, thái độ của thí sinh với bài thi cũng có mối liên quan chặt chẽ với kết quả bài làm. Một số điểm khác biệt khác tương đối rõ thể hiện trong đánh giá của thí sinh về độ khó của bài thi, từ mới hoặc thuật ngữ chuyên môn trong bài thi và độ quen thuộc của các chủ đề trong bài thi. Thí sinh cho rằng bài nghe của đề thi IELTS đỡ khó hơn, có ít từ mới hơn và chủ đề quen thuộc hơn so với bài thi TOEFL iBT. Thí sinh cũng nhận thấy cách thức thi của bài thi IELTS đỡ thách thức hơn so với bài thi TOEFL iBT mặc dù thí sinh thể hiện sự lựa chọn bài thi phụ thuộc rất nhiều vào trải nghiệm đã được chuẩn bị và luyện thi.

Tù khóa: bài thi nghe IELTS, bài thi nghe TOEFL iBT, thái độ của thí sinh thi, nội dung bài thi, phương thức thi, độ khó của bài thi, kết quả thi, lựa chọn bài thi 


\section{APPENDIX 1A \\ Questionnaires for participants after taking the IELTS Listening Test}

(Note. The last column "*Note” in the questionnaire does not appear in the Vietnamese version given to the test takers)

This questionnaire is intended to obtain information about your impression on the IELTS listening test you have just done. Please read each statement carefully and tick in the box to decide your degree of agreement or disagreement.

\begin{tabular}{|c|c|c|c|c|c|}
\hline (6) & (5) & (4) & (3) & (2) & (1) \\
\hline strongly agree & agree & slightly agree & slightly disagree & disagree & strongly disagree \\
\hline
\end{tabular}

\section{A. ABOUT THE TEST AS A WHOLE}

\begin{tabular}{|c|c|c|c|c|c|c|c|}
\hline & (6) & (5) & (4) & (3) & (2) & (1) & *Note \\
\hline 1. I found the test interesting. & & & & & & & \\
\hline 2. I found the test short. & & & & & & & recode \\
\hline 3. I found the speech rate fast. & & & & & & & recode \\
\hline 4. I found some of the accents difficult to understand. & & & & & & & recode \\
\hline 5. I found the test difficult overall. & & & & & & & recode \\
\hline
\end{tabular}

\section{B. TEST INSTRUCTIONS}

\begin{tabular}{|c|c|c|c|c|c|c|c|}
\hline & (6) & (5) & (4) & (3) & (2) & (1) & $*$ Note \\
\hline $\begin{array}{c}\text { 1. I found the test instructions (e.g how many sections, } \\
\text { where and when to write the answers...) clear. }\end{array}$ & & & & & & & \\
\hline
\end{tabular}

C.READING QUESTIONSANDTHE EFFECT OFREADING QUESTIONS BEFORE LISTENING

\begin{tabular}{|c|c|c|c|c|c|c|c|}
\hline $\begin{array}{c}\text { 1. I was given enough time to read questions before } \\
\text { listening. }\end{array}$ & (6) & (5) & (4) & (3) & (2) & (1) & *Note \\
\hline $\begin{array}{c}\text { 2. I found reading the questions before listening } \\
\text { helped my comprehension. }\end{array}$ & & & & & & & \\
\hline $\begin{array}{c}\text { 3. I found it difficult to remember the questions I } \\
\text { read before listening. }\end{array}$ & & & & & & & recode \\
\hline
\end{tabular}

\section{CHALLENGE OF READING QUESTIONS, LISTENING TO STIMULUS AND WRITING}

\section{ANSWERS}

\begin{tabular}{|c|c|c|c|c|c|c|c|}
\hline & (6) & (5) & (4) & (3) & (2) & (1) & *Note \\
\hline $\begin{array}{c}\text { 1. I found it difficult to manage listening to the stimulus, looking } \\
\text { at the question, and writing the answers at the same time. }\end{array}$ & & & & & & & recode \\
\hline $\begin{array}{c}\text { 2. As I had to listen to the stimulus for several questions, I found } \\
\text { it challenging to match a question with the listening stimulus I } \\
\text { was listening to. }\end{array}$ & & & & & & & recode \\
\hline
\end{tabular}


E. TIME ALLOCATION TO CHECK AND TRANSFER THE ANSWERS

\begin{tabular}{|c|c|c|c|c|c|c|c|}
\hline $\begin{array}{c}\text { 1. I had enough time to check my answers after listening } \\
\text { to each section stimulus. }\end{array}$ & (6) & (5) & (4) & (3) & (2) & *Note \\
\hline $\begin{array}{c}\text { 2. I found the one minute allowed for checking all my } \\
\text { answers at the end of the test sufficient. }\end{array}$ & & & & & & & \\
\hline $\begin{array}{c}\text { 3. I found the } 10 \text { minutes allowed for transferring my } \\
\text { answers to the answer sheet sufficient. }\end{array}$ & & & & & & \\
\hline
\end{tabular}

F. DIFFICULTY LEVEL OF EACH SECTION IN THE TEST

\begin{tabular}{|c|c|c|c|c|c|c|c|}
\hline $\begin{array}{c}\text { Section 1: [conversation]: An interview between police } \\
\text { and a witness. }\end{array}$ & & & & & & & \\
$\begin{array}{c}\text { I found this section difficult. } \\
\text { Section 2: [monologue]: A recorded message giving } \\
\text { information about an English hotel. } \\
\text { I found this section difficult. }\end{array}$ & & & & & & & recode \\
\hline $\begin{array}{c}\text { Section 3: [conversation]: Three students talking about } \\
\text { their study programs. }\end{array}$ & & & & & & & recode \\
$\begin{array}{c}\text { I found this section difficult. } \\
\begin{array}{c}\text { Section 4: [monologue]: } \text { A talk by a university lecture } \\
\text { in Australia on a type of bird in Tasmania. } \\
\text { I found this section difficult. }\end{array}\end{array}$ & & & & & & & recode \\
\hline
\end{tabular}

G. NEW WORDS/TECHNICAL TERMS OF EACH SECTION IN THE TEST

\begin{tabular}{|c|c|c|c|c|c|c|c|}
\hline & (6) & (5) & (4) & (3) & (2) & (1) & *Note \\
\hline $\begin{array}{l}\text { Section 1: [conversation]: The interview between police and a } \\
\text { witness. } \\
\begin{aligned} \text { I found that this section has many new words/technical } \\
\text { terms. }\end{aligned}\end{array}$ & & & & & & & recode \\
\hline $\begin{array}{l}\text { Section 2: [monologue]: A recorded message giving } \\
\text { information about an English hotel. } \\
\text { I found that this section has many new words/technical } \\
\text { terms. }\end{array}$ & & & & & & & recode \\
\hline $\begin{array}{l}\text { Section 3: [conversation]: Three students talking about their } \\
\text { study programs. } \\
\begin{array}{l}\text { I found that this section has many new words/technical } \\
\text { terms. }\end{array}\end{array}$ & & & & & & & recode \\
\hline $\begin{array}{l}\text { Section 4: [monologue]: A talk by a university lecture in } \\
\text { Australia on a type of bird in Tasmania. } \\
\text { I found that this section has many new words/technical } \\
\text { terms. }\end{array}$ & & & & & & & recode \\
\hline
\end{tabular}


H. TOPIC FAMILIARITY OF EACH SECTION IN THE TEST

\begin{tabular}{|c|c|c|c|c|c|c|c|}
\hline & (6) & (5) & (4) & (3) & (2) & (1) & *Note \\
\hline $\begin{array}{l}\text { Section 1: [conversation]: An interview between } \\
\text { police and a witness. } \\
\text { I felt that the topic of this interview was familiar. }\end{array}$ & & & & & & & \\
\hline $\begin{array}{l}\text { Section 2: [monologue]: A recorded message giving } \\
\text { information about an English hotel. } \\
\text { I felt that the topic of this interview was familiar. }\end{array}$ & & & & & & & \\
\hline $\begin{array}{l}\text { Section 3: [conversation]: Three students talking } \\
\text { about their study programs. } \\
\text { I felt that the topic of this interview was familiar. }\end{array}$ & & & & & & & \\
\hline $\begin{array}{l}\text { Section 4: [monologue]: A talk by a university lecture } \\
\text { in Australia on a type of bird in Tasmania. } \\
\text { I felt that the topic of this interview was familiar. }\end{array}$ & & & & & & & \\
\hline
\end{tabular}

I. RELATION BETWEEN THE TEST AND LISTENING ABILITY

\begin{tabular}{|l|l|l|l|l|l|l|l|}
\hline & (6) & (5) & (4) & (3) & (2) & (1) & $*$ Note \\
\hline $\begin{array}{l}\text { 1. The score on this test will reflect my true listening } \\
\text { ability }\end{array}$ & & & & & & \\
\hline
\end{tabular}

\section{K. COMPARING TWO TESTS AND MAKING A CHOICE}

(*for those who did TOEFL listening test first and IELTS listening test later)

\begin{tabular}{|l|l|l|l|l|l|l|l|}
\hline & (6) & (5) & (4) & (3) & (2) & (1) & *Note \\
\hline $\begin{array}{l}\text { 1. In general I found the TOEFL listening test more } \\
\text { challenging than the IELTS listening test. }\end{array}$ & & & & & & & \\
\hline $\begin{array}{l}\text { 2. If I had a choice, I would prefer to sit for the IELTS } \\
\text { listening test rather than the TOEFL listening test. }\end{array}$ & & & & & & & \\
\hline
\end{tabular}

\section{APPENDIX 1B}

\section{Questionnaires for participants after taking the TOEFL Listening Test}

(Note. The last column "*Note" in the questionnaire does not appear in the Vietnamese version given to the test takers)

This questionnaire is intended to obtain information about your impression on the TOEFL listening test you have just done. Please read each statement carefully and tick in the box to decide your degree of agreement or disagreement.

\begin{tabular}{|c|c|c|c|c|c|}
\hline (6) & (5) & (4) & (3) & (2) & (1) \\
\hline strongly agree & agree & slightly agree & slightly disagree & disagree & $\begin{array}{c}\text { strongly } \\
\text { disagree }\end{array}$ \\
\hline
\end{tabular}


A. ABOUT THE TEST AS A WHOLE

\begin{tabular}{|l|l|l|l|l|l|l|l|}
\hline & (6) & (5) & (4) & (3) & (2) & (1) & *Note \\
\hline 1. I found the test interesting. & & & & & & & \\
\hline 2. I found the test short. & & & & & & & \\
\hline 3. I found the speech rate fast. & & & & & & & recode \\
\hline 4. I found some of the accent(s) difficult to understand. & & & & & & & recode \\
\hline 5. I found the test difficult overall. & & & & & & & recode \\
\hline
\end{tabular}

\section{B. TEST INSTRUCTIONS}

\begin{tabular}{|l|l|l|l|l|l|l|l|}
\hline & (6) & (5) & (4) & (3) & (2) & (1) & *Note \\
\hline $\begin{array}{l}\text { 1. I found the test instructions (e.g how many sections, } \\
\text { where and when to write the answers...) clear. }\end{array}$ & & & & & & & \\
\hline
\end{tabular}

C. VISUAL STIMULUS AND ITS EFFECT ON COMPREHENSION AND CONCENTRATION

\begin{tabular}{|l|l|l|l|l|l|l|l|}
\hline & (6) & (5) & (4) & (3) & (2) & (1) & *Note \\
\hline $\begin{array}{l}\text { 1. I found the visual stimulus (e.g classroom, lecturer's } \\
\text { office or a library scene) helped my comprehension. }\end{array}$ & & & & & & & \\
\hline $\begin{array}{l}\text { 2. I found visual stimulus (e.g classroom, lecturer's office } \\
\text { or a library scene) distracting as it stayed on the screen. }\end{array}$ & & & & & & & recode \\
\hline $\begin{array}{l}\text { 3. I found that technical terms and/or an illustrative } \\
\text { picture (of what the lecturer was saying) on the screen } \\
\text { helped my comprehension. }\end{array}$ & & & & & & & \\
\hline
\end{tabular}

\section{BEING GIVEN QUESTIONS AFTER LISTENING TO THE STIMULUS AND ANSWERING}

\begin{tabular}{|l|l|l|l|l|l|l|l|}
\hline & (6) & (5) & (4) & (3) & (2) & (1) & *Note \\
\hline $\begin{array}{l}\text { 1. I found seeing the questions after I had listened to } \\
\text { the whole listening stimulus (of each conversation or } \\
\text { lecture) helped my comprehension. }\end{array}$ & & & & & & & \\
\hline $\begin{array}{l}\text { 2. Controlling the speed of answering the questions within } \\
\text { 20 minutes given in this test was good for my performance. }\end{array}$ & & & & & & & \\
\hline
\end{tabular}

\section{E. TIME ALLOCATION TO CHECK AND TRANSFER THE ANSWERS}

\begin{tabular}{|l|l|l|l|l|l|l|l|}
\hline & (6) & (5) & (4) & (3) & (2) & (1) & *Note \\
\hline $\begin{array}{l}\text { 1. I found the overall time of 20 minutes given to } \\
\text { answer all the questions in this listening test sufficient. }\end{array}$ & & & & & & & \\
\hline
\end{tabular}

\section{F. DIFFICULTY LEVEL OF EACH SECTION IN THE TEST}

\begin{tabular}{|l|l|l|l|l|l|l|l|}
\hline \multicolumn{1}{|c|}{ Part 1 } & (6) & (5) & (4) & (3) & (2) & (1) & *Note \\
\hline $\begin{array}{l}\text { Conversation 1.2: A talk between a lecturer and a } \\
\text { student about her missing from class and the handout } \\
\text { she missed. } \\
\text { I found this conversation difficult. }\end{array}$ & & & & & & & \\
\hline $\begin{array}{l}\text { Lecture 1.1: Biology: sound development in birds } \\
\text { I found this conversation difficult. }\end{array}$ & & & & & & & \\
\hline
\end{tabular}




\begin{tabular}{|l|l|l|l|l|l|l|l|}
\hline $\begin{array}{l}\text { Lecture 1.2: History: development of a historical place } \\
\text { I found this conversation difficult. }\end{array}$ & & & & & & & recode \\
\hline \multicolumn{1}{|c|}{ Part 2 } & (6) & (5) & (4) & (3) & (2) & (1) & \\
\hline $\begin{array}{l}\text { Conversation 2.1: A talk between a student and a } \\
\text { librarian about looking for reference books in the library } \\
\text { I found this conversation difficult. }\end{array}$ & & & & & & & \\
\hline $\begin{array}{l}\text { Lecture 2.1: Business } \\
\text { I found this conversation difficult. }\end{array}$ & & & & & & & recode \\
\hline $\begin{array}{l}\text { Lecture 2.2: Astronomy } \\
\text { I found this conversation difficult. }\end{array}$ & & & & & & & recode \\
\hline
\end{tabular}

\section{G. TECHNICAL TERMS IN EACH LISTENING PARTS}

\begin{tabular}{|c|c|c|c|c|c|c|c|}
\hline Part 1 & (6) & (5) & (4) & (3) & (2) & (1) & *Note \\
\hline $\begin{array}{l}\text { Conversation 1.1: A talk between a lecturer and a } \\
\text { student about her missing from class and the handout } \\
\text { she missed } \\
\text { I found that this section has many new words/technical } \\
\text { terms. }\end{array}$ & & & & & & & recode \\
\hline $\begin{array}{l}\text { Lecture 1.1: Biology: sound development in birds } \\
\text { I found that this section has many new words/technical } \\
\text { terms. }\end{array}$ & & & & & & & recode \\
\hline $\begin{array}{l}\text { Lecture 1.2: History: development of a historical place. } \\
\text { I found that this section has many new words/technical terms. }\end{array}$ & & & & & & & recode \\
\hline Part 2 & (6) & (5) & (4) & (3) & (2) & (1) & \\
\hline $\begin{array}{l}\text { Conversation 2.1: A talk between a student and a librarian } \\
\text { about looking for reference books in the library } \\
\text { I found that this section has many new words/technical } \\
\text { terms. }\end{array}$ & & & & & & & recode \\
\hline $\begin{array}{l}\text { Lecture } 2.1: \text { Business } \\
\text { I found that this section has many new words/technical } \\
\text { terms. }\end{array}$ & & & & & & & recode \\
\hline $\begin{array}{l}\text { Lecture } 2.2: \text { Astronomy } \\
\text { I found that this section has many new words/technical } \\
\text { terms. }\end{array}$ & & & & & & & recode \\
\hline
\end{tabular}

\section{H. TOPIC FAMILIARITY}

\begin{tabular}{|l|l|l|l|l|l|l|l|}
\hline \multicolumn{1}{|c|}{ Part 1 } & (6) & (5) & (4) & (3) & (2) & (1) & *Note \\
\hline $\begin{array}{l}\text { Conversation 1.2: A talk between a lecturer and a student } \\
\text { about her missing from class and the handout she missed } \\
\text { I felt that the topic of this conversation was familiar. }\end{array}$ & & & & & & & \\
\hline $\begin{array}{l}\text { Lecture 1.1: Biology: sound development in birds } \\
\text { I felt that the topic of this lecture was familiar to me. }\end{array}$ & & & & & & & \\
\hline
\end{tabular}


Lecture 1.2: History: development of a historical place. I felt that the topic of this lecture was familiar to me.

\begin{tabular}{|c|c|c|c|c|c|c|}
\hline Part 2 & (6) & (5) & (4) & (3) & (2) & (1) \\
\hline $\begin{array}{l}\text { Conversation 2.1: A talk between a student and a librari } \\
\text { about looking for reference books in the library } \\
\text { I felt that the topic of this conversation was familiar. }\end{array}$ & & & & & & \\
\hline $\begin{array}{l}\text { Lecture 2.1: Business } \\
\text { I felt that the topic of this lecture was familiar to me. }\end{array}$ & & & & & & \\
\hline $\begin{array}{l}\text { Lecture } 2.2 \text { : Astronomy } \\
\text { I felt that the topic of this lecture was familiar to me. }\end{array}$ & & & & & & \\
\hline
\end{tabular}

I. RELATION BETWEEN THE LISTENING TEST AND LISTENING ABILITY

\begin{tabular}{|l|l|l|l|l|l|l|l|}
\hline & (6) & (5) & (4) & (3) & (2) & (1) & *Note \\
\hline $\begin{array}{l}\text { 1. The score in this test will reflect my true listening } \\
\text { ability }\end{array}$ & & & & & & \\
\hline
\end{tabular}

K. COMPARING TWO TEST AND MAKING A CHOICE

(for those who did IELTS listening test first and TOEFL listening test later)

\begin{tabular}{|l|l|l|l|l|l|l|l|}
\hline & (6) & (5) & (4) & (3) & (2) & (1) & *Note \\
\hline $\begin{array}{l}\text { 1. In general I found the IELTS listening test more } \\
\text { challenging than the TOEFL listening test. }\end{array}$ & & & & & & & \\
\hline $\begin{array}{l}\text { 2. If I had a choice, I would prefer to sit for the IELTS } \\
\text { listening test rather than the TOEFL listening test. }\end{array}$ & & & & & & & \\
\hline
\end{tabular}

